\title{
E-learning Tools to Improve Students' Learning Experience: a case study
}

\author{
Baomin Qi and Lu Liu \\ Bolton Business School, University of Bolton, Bolton, UK \\ Email: bq2@bolton.ac.uk \\ Chengbo Wang \\ Caledonian Business School, University of Glasgow, Glasgow, UK \\ Email: cwa1@gcal.ac.uk
}

\begin{abstract}
E-learning refers to the way people communicate and learn electronically which has only recently emerged as a key source of competitive advantage in the information society. With the development of the Information and Communication Technologies, E-Learning is argued to become a new and effective learning method and environment besides classroom based learning. Although still an emerging field, many researchers suggest that it offers many benefits that are radically different from a conventional classroom-based learning environment and can still generate result for students. It could be providing independent learning programme for internal students, external students, distant students, and training purpose. However, it is also revealed in literature that E-Learning has been used more indirectly as a tool for organising study courses and educational programmes. The questions such as "can E-Learning be made as a learning strategy" and "can E-Learning replace classroom-based modes of learning and teaching" remain unanswered. This research intends to explore various aspects with regards to how and to what extent E-Learning has been used to improve teaching and learning activities using the University of Bolton as a case study. It also intends to verify the main findings from the literature review via employing a case study approach and hence make comparisons between the national trends of $\mathrm{E}$ Learning usage and the chosen case. The main research findings from this study are presented in this paper.
\end{abstract}

Index Terms-E-Learning tools; Higher Education Institutes; case study

\section{INTRODUCTION}

With the development of information technology, eplus functions have been gradually replacing traditional activities to dominate both practice and academic research. E-Business, E-Government, E- Banking, and other such "E" words have appeared and become globally popular. E-Learning (EL) is one of them. EL refers to the way people communicate and learn electronically (Roffe, 2002). In Higher Education Institutions (HEIs), EL programs are applied in three different areas to fulfill different demands-off-campus study programs for

Manuscript received January 1, 2009; revised June 1, 2009; accepted July 1, 2009. classroom-based students; online distance study programs for distant students and E-Learning/Training programs for organizations.

This study is a part of IS\&T development project funded by the University of Bolton (UB), of which the aim is to develop strategies for UB information systems and technologies (IS\&T) service adaptation and application. The focus of this study is E-Learning that includes both tools application and virtual learning environment improvement. The first stage of this study is to explore the first two areas presented above to find out how current students utilize the available EL tools and channels and how they evaluate them. This is because students' experiences, demands and willingness toward using EL tools and channels are the key issues for HEIs to further develop proper and effective EL programs.

Additionally, in the last two decades, HEIs and the government have consistently committed themselves to invest and introduce Information and Communications Technology (ICT) for teaching and learning purposes. ICT has been widely adopted at aiming to provide greater access for different target learners and has become vehicles for enriched pedagogical experiences. The underpinning assumption is that the use of ICT should allow universities to enhance their competence and compatibility and fundamentally change their teaching and learning environment. Based on this assumption, the development and implementation of EL tools and channels has become the dominant area among those investments (UNESCO, 2003). However, as revealed in literature, EL has been used more indirectly as a tool for organizing study courses and educational programs. The questions of 'can E-Learning be made as a learning strategy and can EL replace classroom-based modes of learning and teaching' remain unanswered.

Therefore, this study will start with the discussion on ICT implementation in HEIs and then focus on ELearning. Through literature review and authors' practices, this research intends to explore various aspects with regards to how and to what extent EL tools have been used to improve teaching and learning activities in the University of Bolton as a case study. The study also intends to verify the main findings from the literature review via employing a case study approach and hence 
make comparisons between the national trends in EL usage and the chosen case.

\section{LITERATURE REVIEW}

\section{A. ICT Adoption Evolution in HEIs}

The use of ICT in HEIs has encountered three phases (Martin, 2002), which reflects those of the development of information technologies. From the 1960s until the end of 1980s, this phase was called the mastery phase with emphasis on gaining knowledge and skill of a computer, e.g. how a computer worked and how to program. Many assumptions were made to indicate how a computer could be used in education, such as, to usurp the traditional functions of libraries. However, the lack of financial support, educational software, and staff experience in the use of computers were major obstacles to prevent ICT becoming integrated in teaching and learning (McDonough, 1986). Therefore, the use of ICT in HEIs was very limited at this stage.

From the 1980s till the end of 1990s is called the application phase with emphasis on using intuitive graphical user interface-based applications such as word processing, spreadsheets and databases. In HEIs, computers and generic applications as well as self-study leaflets were provided for students to gain knowledge and be literate in ICT. Many HEIs were required to integrate ICT skills development into their subject courses. However, there was little incentive to engage academics in IT-based teaching. Although in 1991, the Teaching and Learning Technology Program (TLTP) initiated some projects to promote the use of ICT in teaching, at this stage the main development of promoting ICT in HEIs was still largely limited in areas for students to gain skills and knowledge on computers (Martin, 2002).

From the end of 1990s to date is called the reflective phase. Because of the evolutional change of teachercentred teaching and learning models to learner-centred models, it was perceived that "for Higher Education to move forward, a whole perspective on the nature of the learning environment must be maintained, with more student-focused learning approaches matched by a suffusion of ICT across curriculum and pedagogy" (Collis and Van der Wende, 2002). At this stage, emphasis has been placed on how ICT can be used in education by offering a variety of teaching methodologies including distance and resource-based modes. This implies that because the new ICT technology is changing the way information is stored and transmitted, HEIs need to look for ways in which it is delivered. Examples of ICT developments assisting teaching and learning include 'hybrid library' to access to ICT-based resources as well as traditional paper-based stock, virtual learning environments (VLMs) for students accessing a range of online resources with built-in tools and interactive facilities to enhance the students' experience (ibid).

These three phases demonstrates the increasing use of ICT in HEIs. As in many areas, ICT has been perceived to have positive effects to enhance teaching and learning.

\section{B. ICT Initiatives and Implementation Issues in HEIs}

Studies (Stensaker, 2007; Fallshaw, 2000) have suggested some strategies or check-lists for the adaptation of ICT in HEIs including a well-defined institutional ICT strategy in line with the corporate strategy, the commitment and involvement of the institutional topmanagement, the need to link ICT to organizational development initiatives, and the availability of technical support and skills, etc. However, the factors revealed in literature have hardly stressed the pedagogical aspect as to how ICT could be used to improve teaching and learning. It has been mostly incorporated for administrative reasons such as student registration or offering practical information on websites. The integration of ICT in teaching and learning strategy is still largely limited. This suggests that the adaptation of ICT in HEIs is largely driven by the extensive external pressure rather than the actual needs of using ICT. Therefore, when initiating an ICT strategy most of HEIs only emphasized on adoption strategies, infrastructures and new institutional visions rather than how to integrate ICT in the teaching and learning process (Bates, 2000).

One of the barriers for successful implementation of ICT initiatives is that staff should be given support such as time and training for development and updating of ICT-based materials (Lewis and Goodison, 2004). As discussed by Löfström and Nevgi (2007), one of the issues in relation to the support that staff get, is how far staff should be supported in order to generalize the use of ICT. Another issue is to integrate into staff timetables to replace face-to-face relationship to online tutoring. The implementation of ICT into learning and teaching in HEIs also raises the question of the incentive for staff to engage in such developments. The involvement of academic staff is still very limited, and a lot of staff have not even been involved at all (Becta, 2008). Therefore, the successful implementation of ICT initiatives should provide staff with adequate ICT training and raise their ICT level of skills as a whole. The implementation of ICT largely depends on a strong central strategy in an organization pushing forward an agenda for change. Ellis and Moore (2006) also revealed that the integration of ICT in teaching and learning should follow a team-based approach requiring expertise and involvement from more than one person so that the existence of a supportive and responsive team is able to respond to the needs of individual staff members.

\section{Current E-Learning Application in HEIs}

E-Learning refers to the way people communicate and learn electronically which has only recently emerged as a key source of competitive advantage in the information society (Roffe, 2002). With the quick development of ICT, EL is becoming a new, effective learning method alongside class-room learning. Although still an emerging field, it offers many benefits that are radically different from a conventional classroom-based learning environment and can still generate results for students, i.e. just-in time; accessible from any site with the right equipment; cost-effectiveness; personalization; learner 
centered learning; contemporary; scalable structure; interactivity; uniformity of content; content updated rapidly; blindness of the learning engagement; and measurement of program performance, etc (ibid). EL also provides possibilities for educationalists as enhanced access; more flexible learning; extending the range of influence; and deepening the penetration for learning. Therefore, EL could be providing learning programs for internal students, external students, distant students, and training (ibid). Thus, the argument, on which researchers focus, is not about whether to adopt or not to adopt EL for higher education, but how to implement it to offer a high quality learning experience.

Regardless of the reason for the investment decisions, much of the activity in EL is taking place at the level of development of courses and their resources. Only a small number of institutions have recognized that successful EL takes place within a complex system, composed of many interrelated parts, where failure of only one part of that system can cause the entire initiative to fail (Alexander, 2001).

E-Learning brings innovation to both teaching and learning experiences, no matter the adoption is either because of proactive future orientation or reaction to whether competition pressure. It is not that the innovation should not come from outside of education, or that it can only come from within. It is simply that innovations must be presented in terms that are meaningful for teaching practice. New technology or teaching methods adoption will only increase significantly when innovations possess some of the following characteristics: simplicity; compatibility with existing methods and techniques; and relative advantages in comparison with these established methods and techniques (Carlsson, 2003).

Currently, both HEIs and the government have invested heavily on E-Learning technologies such as WebCT, Blackboard and Moodle (UNESCO, 2003). However, studies reveal that most of HEIs have only made limited formal academic use of EL tools for teaching and learning purpose (Selwyn, 2006; Ellis and Moore, 2005). Selwyn (2006) argues that the only way to achieve meaningful change in the ways in which computer technologies are used in EL is to strive to engineer a radical overall and wholesale restructuring of universities and university education.

For universities that substantially use a web-based virtual learning environment (VLE), almost all of them post core information about courses or taught topics electronically (Lewis and Goodison, 2004). Oliver (2002) found that VLE promoted independent leaning especially through access to up-to-date materials such as e-books and e-journals. He also indicated that, in order to be successful, EL initiatives should be driven by pedagogy, not technology. However, staff training in most of EL initiatives has more focused on the technology rather than on pedagogic issues (Lewis and Goodison, 2004).

There has also been an increase in the use of online tutorials to replace some core lectures. Group interaction and shared learning are featured prominently in subject developments. From their study, Lewis and Goodison
(2004) indicated the improvement in the level and quality of teaching preparation. This includes: materials could be easily updated and revised to suit the needs of different student groups; lecture notes can be posted on the intranet in advance giving students freedom to concentrate on important concepts or issues within the content; and students are better prepared and are likely more engaged. However, the research also revealed that only limited functions have been used by most staff in most institutions. The pedagogic use of EL rarely went beyond the posting and retrieval of routine course information.

Issroff and Scanlon (2002) stated that EL approaches have enabled students to work at their own pace, in their own time and chosen location, therefore increased diverse recruitment such as working people and disabled people. The interactive nature of EL tools could add value to learning, but this facility had yet to be fully exploited. This study also indicated that the use of EL in HEIs could enhance active learning by providing a range of resources and communication facilities for students.

Oliver (2002) revealed that EL initiatives have changed the way in which students learn. He, Duffy and Cunningham (1996) both stated that the use of EL could transform education from teacher-centered learning to student-centered learning, and provided strengths of constructive learning which emphasizes learning as a process of knowledge construction rather than the memorization of facts.

Breen et. al. (2001) argues that although EL is often associated with the efficiency of delivering and supporting learning over traditional resource-based learning methods, its reality is far from these. Their study revealed that EL tools have become central to students' experience as a learning support. Löfström and Nevgi (2007) reported in a study on strategic planning and implementation of EL in teaching that the use of EL tools can enhance teaching and assure student information literacy. Two basic functions of EL tools in teaching were identified including: distribution of course material via the web, and the creation of interactive and collaborative learning opportunities. However, the level of quality in terms of web-based teaching should be made aware to ensure the quality of learning.

From the above research review, an ambiguity of the content of E-Learning can be found. Some researchers regard EL as a teaching and learning method (Roff, 2002; Alexander, 2001; and Carlsson, 2003), while some other researchers regard EL as the tools or technologies to facilitate the teaching and learning process (Selwyn, 2006; Ellis and Moore, 2005). And some other researchers refer EL to the both (Oliver, 2002; Lewis and Goodison, 2004; Issroff and Scanlon, 2002). In this study, the last standpoint is adopted that when conducting case study, the authors refer EL as all the activities that students and teachers do in virtual environment.

\section{RESEARCh MEthodology}

This study adopts an exploratory route, and applies a quantitative and qualitative combination case study research approach from employing mixed research 
methods including survey and focused group interview. This research approach represents E-Learning development in HEIs where the focus revolves around how current EL tools and channels are used by students and tutors for the purpose of satisfying their study and teaching needs and they should be adapted and developed. Archival analysis and case study are the main research methods used in this study. Archival analysis is used to explore the existing literature and documents for findings and practices in the subject. According to Yin (2003) a case study is a comprehensive description and analysis of a single situation. In case studies the aim of the research is to seek conformity between the results and the theory and a qualitative case study approach has a distinct advantage when the "how" or "why" question is being asked about a contemporary set of events over which the investigator has little or no control. Therefore, to achieve the aim of this study, a case study approach best suits this study.

In the first stage of this case study, a questionnaire based survey was employed to investigate the current situation of EL utilization among students in the sample university. Other qualitative methods such as interview will be adopted to conduct the second stage which the focus is to explore deep-seated reasons behind survey answers. Although this study employed a survey method, the authors' intention is to describe the phenomena and to explore the essence behind the phenomena rather than gathering statistical data to predict the future trend.

As it is indicated previously that this study is funded by the University of Bolton, UB is chosen as the case. Sample selection focused on all students and teaching staff in the UB. WebCT is a virtual learning portal which is the dominant EL application for all UB students and staff. Prior to the other EL facilities (computer, internet, email and designed software for particular modules), current WebCT usage statue in the UB is chosen to be the first step study of this research.

Because students are the dominant users of WebCT, they are the main target at this stage. Sample selection criteria focus on students from different programs and levels. Various students have been chosen from the Business School for the first survey. They are master's degree students, undergraduate students from the first and second year, exchange students from Germany and distance students from Vietnam. Master students are selected because most of them have graduated from the same university. They are familiar with using WebCT and have experienced the changes over several years. First year students are new to the university and should receive attention from all aspects. Learning to use WebCT, which will be part of their study for several years, is one of the key steps for these young people to successfully achieve their new study process. The second year students will tell us their experiences from the first year. Exchange students are the challenges to the WebCT designer sand managers, for they are new users and only stay for a very short period. It is extremely important to know the problems that distance students have encountered.
A tailored questionnaire was designed from a jointwork of both the researchers and the WebCT manager. It was modified several times by pilot testing amongst different people, including students, tutors and administrators. In order to receive the largest responses, questionnaires were handed out directly to the target students in classes. It was the same for the distance students. Questionnaires were distributed and collected by the tutor who went to Vietnam for teaching. Questionnaires were completed in anonymous way.

After the first round of the survey, the authors carefully examined and recorded the results (Qi, Liu, Wang, Oliver and Zhang 2009) and then revised the questionnaire to make it more comprehensive and focused. Besides adding specific open questions to the questionnaire, part-time students also became the main focus. Open questions were designed to explore reasons behind some multiple-choice questions in the first survey. Part-time students have not been differentiated from fulltime students. This shortcoming made the first survey incomplete. These two surveys targeted the same group of students. This paper combined the result from those two surveys.

\section{CASE Study}

The University of Bolton is a small institution with a diverse student community. It has a student body of around 9,000 and around 1,000 further at overseas centers, who are enrolled at the university. More than 70 per cent of campus-based and franchise students come from the North West of England. Over 50\% of these students study part time and over $75 \%$ are mature students. It has 5 academic schools and 2 research centers which offer degree and training courses in a wide range of subject areas. This diverse student community has presented some major challenges for its management (UB website, 2008).

\section{A. General Usage}

From the first survey, it is found that $85 \%$ of students feel using WebCT contributed to their study. $44 \%$ of the students use WebCT daily and $41 \%$ of the students use WebCT weekly. $37.5 \%$ of the students estimate their study time of using WebCT as 25 per cent to $50 \%$ and $49 \%$ of the students estimate their study time of using WebCT as less than $25 \%$. These results show that WebCT plays an important role in students' study but does not hugely occupy their study time. $78.75 \%$ of students feel WebCT is user friendly and easy to navigate, $13.75 \%$ of students do not care about this issue and only $8.50 \%$ of students disagree on this point. This shows that WebCT as a virtual learning portal is successfully accepted by most of the students (Qi, et al., 2009).

The following table (Table 1) shows how the students use WebCT and how much they know about WebCT and what their expectations are from WebCT. 
TABLE I. GENERAL WEBCT USAGE

\begin{tabular}{|c|c|c|c|c|c|c|}
\hline $\begin{array}{c}\text { Type of } \\
\text { Tool / } \\
\text { Resource }\end{array}$ & $\begin{array}{c}\text { Availa } \\
\text { ble in } \\
\text { WebC } \\
T\end{array}$ & $\begin{array}{c}\text { Used in } \\
\text { WebC } \\
\quad T\end{array}$ & $\begin{array}{c}\text { Want to } \\
\text { use if } \\
\text { available } \\
\text { in } \\
\text { WebCT }\end{array}$ & $\begin{array}{c}\text { Used } \\
\text { by you } \\
\text { outside } \\
\text { WebC } \\
\text { T }\end{array}$ & $\begin{array}{c}\text { Don' } \\
\text { t } \\
\text { know } \\
\text { what } \\
\text { it is }\end{array}$ & $\begin{array}{l}\text { Like } \\
\text { to } \\
\text { have } \\
\text { train } \\
\text { ing } \\
\end{array}$ \\
\hline $\begin{array}{l}\text { Video } \\
\text { Lecture }\end{array}$ & $3.75 \%$ & $3.75 \%$ & $73.75 \%$ & $8.75 \%$ & $2.5 \%$ & $15 \%$ \\
\hline $\begin{array}{l}\text { Online } \\
\text { materials }\end{array}$ & $52.5 \%$ & $60 \%$ & $62.5 \%$ & $\begin{array}{l}21.25 \\
\% \\
\end{array}$ & 0 & $\begin{array}{l}3.75 \\
\% \\
\end{array}$ \\
\hline $\begin{array}{l}\text { Online } \\
\text { presentat } \\
\text { ions }\end{array}$ & $27.5 \%$ & $37.5 \%$ & $66.25 \%$ & $20 \%$ & $2.5 \%$ & $10 \%$ \\
\hline $\begin{array}{l}\text { Interacti } \\
\text { ve } \\
\text { learning }\end{array}$ & $\begin{array}{l}28.75 \\
\%\end{array}$ & $\begin{array}{l}16.25 \\
\%\end{array}$ & $66.25 \%$ & $\begin{array}{l}18.75 \\
\%\end{array}$ & $\begin{array}{l}1.25 \\
\%\end{array}$ & $10 \%$ \\
\hline $\begin{array}{l}\text { Discussi } \\
\text { on board }\end{array}$ & 43.75 & $15 \%$ & $43.75 \%$ & $15 \%$ & $\begin{array}{l}3.75 \\
\% \\
\end{array}$ & $5 \%$ \\
\hline Email & $42.5 \%$ & $55 \%$ & $42.65 \%$ & $\begin{array}{l}26.25 \\
\% \\
\end{array}$ & $\begin{array}{l}1.25 \\
\% \\
\end{array}$ & $\begin{array}{l}1.25 \\
\% \\
\end{array}$ \\
\hline $\begin{array}{l}\text { Chat } \\
\text { room }\end{array}$ & $\begin{array}{l}33.75 \\
\% \\
\end{array}$ & $10 \%$ & $35 \%$ & $22.5 \%$ & $7.5 \%$ & $\begin{array}{l}6.25 \\
\% \\
\end{array}$ \\
\hline Blogs & $15 \%$ & $1.25 \%$ & $28.75 \%$ & $17.5 \%$ & $\begin{array}{l}12.5 \\
\%\end{array}$ & $\begin{array}{l}3.75 \\
\%\end{array}$ \\
\hline $\begin{array}{l}\text { Group } \\
\text { commun } \\
\text { ication }\end{array}$ & $40 \%$ & $\begin{array}{l}23.75 \\
\%\end{array}$ & $43.75 \%$ & $\begin{array}{l}16.25 \\
\%\end{array}$ & $5 \%$ & $5 \%$ \\
\hline Games & $1.25 \%$ & $2.5 \%$ & $28.75 \%$ & $\begin{array}{l}23.75 \\
\% \\
\end{array}$ & $\begin{array}{l}12.5 \\
\% \\
\end{array}$ & $5 \%$ \\
\hline Wikis & $1.25 \%$ & $1.25 \%$ & $35 \%$ & $22.5 \%$ & $\begin{array}{l}26.2 \\
5 \\
\end{array}$ & $\begin{array}{l}6.25 \\
\% \\
\end{array}$ \\
\hline $\begin{array}{l}\text { MySpac } \\
\text { e }\end{array}$ & $2.5 \%$ & $2.5 \%$ & $37.5 \%$ & $17.5 \%$ & $\begin{array}{l}12.5 \\
\% \\
\end{array}$ & $2 . \%$ \\
\hline
\end{tabular}

From this table, it can be observed that the most frequently used function in WebCT is online materials. This includes a range of electronic materials such as lecture notes and slides, assignment, addition reading material, e-journal and e-books, etc. Students have noticed the other functions, for example, interactive learning, discussion board, and group communication, but they lack the interest to use them. Some functions are actually not available in WebCT, i.e., online presentations, chat room, blogs, games, wikis and MySpace but apparently students have not explored WebCT deeply so they are unaware of the exact functions available. This especially happens to first year students, exchange students and new master students. $82 \%$ of them went to WebCT as advised by their tutors and navigated straight away without any interest to explore other parts of WebCT (Qi, et al, 2009).

As to the Email, as shown in table, $55 \%$ of students are using the WebCT mailbox to communicate with tutors and fellow students. The reason for this high rate is supposed to that some students mixed this WebCT mailbox with their own school email box. When going back to the targeted students, this assumption is proved to be true. $68 \%$ of students do not know there is a mailbox on WebCT where they can leave messages to their tutors and $87 \%$ of students have never used this function (ibid).

From the column "want to use if available in WebCT", there are a high number of students willing to use these currently "not available" functions when they are available. These functions include video lecture, online presentations, chat rooms, Blogs, Wikis and MySpace, etc. All of the part-time students are anxious to have the video lecture function available in order not to lose a lecture if they cannot make it. Therefore, current WebCT does not have sufficient functions to fulfill students' needs. Students have a high expectation of using WebCT effectively and are ready to use it (ibid).

From the first survey, it is also revealed that training is a key issue that affects WebCT utility. $66.25 \%$ of student regards WebCT user training as useful and necessary, but $52.5 \%$ of them found their level of training is insufficient. $71.25 \%$ of students believe their tutors will benefit from developing skills in using WebCT to improve the quality of teaching and learning for their students so as to support them online. At the moment, students are only trained by their tutors, but $65 \%$ of students believe that it will be more beneficial if both tutor and WebCT technical staff can give training. This prompts the question that if students are not confident with their tutors' capacity of using WebCT, how can they be well trained and encouraged to use WebCT? (ibid)

From the second survey, the following findings are exposed.

\section{A. Communications}

WebCT provides both email box and discussion board to facilitate communications. The following results show how students use and evaluate these communication channels.

Student to student - Only $11.25 \%$ of students communicate with their fellow students inside WebCT, $21.25 \%$ of students communicate with their fellow students outside WebCT and $52.5 \%$ of students use both.

Student to tutor - $22.5 \%$ of students communicate with their tutors inside WebCT, and the same $22.5 \%$ of students communicate with their tutors outside WebCT and $55 \%$ use the both.

For the distance students, only $12 \%$ use WebCT to communicate with their fellow students and tutors. $83 \%$ communicate with other students outside of WebCT. $94 \%$ use the opportunity of face to face tutorial to communicate with their tutors.

One reason why students are not interested in using WebCT is because they prefer face to face communication, especially with tutors. The other one is because they feel other students do not like to use WebCT and some tutors are not interested in using WebCT as well. Some of them who have used mail box and discussion board to give comments or to ask questions complained that few of them were anwered. They found outside WebCT, using common communication methods, i.e., telephone call, face to face talking and email are more effective and comfortable to get in touch with other people.

\section{B. WebCT development and improvement}

Several questions regarding WebCT improvement were added to the second survey. These questions were answered by students from second year to master level both on campus and distance students. This is because first year and exchange students are new to WebCT that 
their experience time is too short to spot the changes. The following table (Table 2) shows the results.

TABLEII. WebCT Improvement Investigation

\begin{tabular}{|c|c|c|c|c|}
\hline & No & A little & A lot & $\begin{array}{c}\text { Pay no } \\
\text { attention }\end{array}$ \\
\hline $\begin{array}{l}\text { Layout of main } \\
\text { page }\end{array}$ & $4.44 \%$ & $22.2 \%$ & $6.67 \%$ & $46.7 \%$ \\
\hline Colour scheme & $6.67 \%$ & $28.9 \%$ & $2.22 \%$ & $46.7 \%$ \\
\hline Navigation & $2.22 \%$ & $20 \%$ & $6.67 \%$ & $42.2 \%$ \\
\hline $\begin{array}{l}\text { Teacher's } \\
\text { providing }\end{array}$ & $4.4 \%$ & $20 \%$ & $11.1 \%$ & $37.8 \%$ \\
\hline Student skills & $2.22 \%$ & $26.7 \%$ & $6.67 \%$ & $33.3 \%$ \\
\hline $\begin{array}{l}\text { Teacher's } \\
\text { training }\end{array}$ & $4.44 \%$ & $20 \%$ & $11.1 \%$ & $31.1 \%$ \\
\hline
\end{tabular}

From the WebCT officer, the authors learned that, since. WebCT was introduced to the UB, only small changes and up-grades have been made to WebCT. The entire version up-grade has not been made until now. One reason is because the lack of suggestions or clearly addressed demands from both students and tutors on what should be changed or how the changes should be made. The other reason is due to lack of support from senior management for further investment on WebCT development and improvement has not been seriously considered. From the survey results, the above first reason was proved by that nearly half of the students are not concerned about the development and improvement of the WebCT. Some students made comments that they have never been asked to give their opinions. Some other comments said that tutors have not provided enough information. To access available information, current WebCT functions and tools were enough, and therefore the students had no motivation to use WebCT innovatively.

\section{WebCT Experiences from Different Levels of Student}

There are different demands from different levels of student. The first survey focused on students from all aspects. The second survey focused on part-time students. The followings are the feedbacks from them.

New students (including exchange students)

First year students believe that WebCT is a good place to acquire lecture materials and it increases the level of interaction between lecturers and students, but they need more training prior to the start of their learning process. New master students also appreciate the learning materials that their tutors provide online but they require the most on video lecture facilities. This is because most of them are part-time students. Exchange students do not pay much attention to WebCT functions if they can find what their tutor wants them to use. This is understandable because they only stay for a short time, but they experience difficulties in using WebCT due to a lack of training.

Second year students
Besides online learning materials, second year students start to explore more specific features of WebCT but they found that they lack professional supervision. They do not know who to go to when encountering problems when using WebCT. They also want their tutors to be encouraged to use more of WebCT functionality. Master students

These students have been using WebCT since their first year of undergraduate study. They feel the functions and developments of WebCT are not enough for them to learn innovatively. They believe that WebCT should be more simple and easier to use and a step-by-step training module should be provided for new users. Besides learning materials, they want WebCT to be livelier, for example, more interaction between tutors and students, such as effectively using the discussion board, creating a virtual conference room or chat room or adopting similar MSN functions; and more events and news that happen on campus. They require more functions available on WebCT, such as new material loaded alert; subject related games; and own subject wikis which is developed by tutors and students. More encouragement should be given to both tutors and students to use WebCT, because they find some tutors are not interested in using WebCT and a few of them do not use it. Students also gradually lose interest in using WebCT except searching for learning material because there are not many changes since they started to use it and students are not graded for using same. Some of them believe WebCT should be integrated as part of their study.

\section{Distance students}

Distance students have not, as expected, used WebCT more than on campus students. They encounter problems with WebCT as training is not enough and cannot obtain support online. In some countries or areas, sometimes loading speed is too slow to open files. Very often, students cannot expect a quick response from tutors and sometimes tutors do not reply to them. There are not enough communication tools for distance students to contact their tutors. Therefore, distance students usually leave most of their questions to face to face tutorials but time may be too short to answer all the questions.

\section{Part-time students}

In the second survey, part-time students were studied because their particularity was neglected in the first survey. They were spending more time on WebCT than full-time students. More that $40 \%$ of part-time students access WebCT more than once per day and more than $30 \%$ use it daily. $52.5 \%$ of the students estimate their study time of using WebCT as $50 \%$ to $75 \%$ and $36.6 \%$ of the students estimate their study time of using WebCT as $25 \%$ to $50 \%$. These results show that WebCT plays a dominant role in the study of part-time students. Comparing with that $78.75 \%$ of full-time students feel that WebCT is user friendly and easy to navigate, only $56 \%$ of part-time students think so. The reason was exposed from their comments that they feel lack of trainings to navigate WebCT effectively. Some of the students complained about spending a lot of time on finding the right place. As with full-time students, the 
most frequently used function by part-time students are online materials. This includes a range of electronic materials such as lecture notes and slides, assignments, additional reading material, e-journals and e-books, etc., while part-time students strongly want to have video or audio lectures available in the WebCT. They also request to implement the ground discussion board which already exists in the WebCT but has been ignored by most of the tutors and students. Differing from full-time students, $48.7 \%$ of part-time students observed the changes of layout and colour of WebCT which also proved that they are using WebCT often and regular. Because they do not come to the campus as often as full-time students, parttime students suggest that WebCT should contain news, events and lively information regarding university's daily life.

\section{RESEARCH FINDINGS}

\section{A. Findings from the Case Study}

As indicated in Section One, the aim of this study is to explore the current situation of students' EL tools adoption and usage in HEIs by employing a case study approach. It is revealed that most students have recognized EL tools as powerful learning options or channels but these tools have not be integrated into teaching strategies and are not adopted to the pedagogic level. Reflected from students' comments, tutors' adoption of WebCT is limited to only providing electronic learning material. Interactive functions such as email box and discussion board are seldom used. This especially affects distance students for using EL tools. From the case study, it is found that distance students do not spend more time on WebCT than campus students (as assumed) because they encounter various problems. One of these problems is that they cannot receive a quick reply from their tutors and they are not encouraged to use interactive functions. This shows that some tutors have not realized the different demands between distance students and campus students or have not recognized the advantages that EL tools can bring to distance students. This ignorance may become a fatal problem for the success of EL programs.

Full-time students prefer to communicate with tutors and fellow students directly while part-time students have stronger demands on EL facilities. This finding may be obvious because part-time students cannot spend as much time as full-time students on group work or group meetings. However, this obvious demand from part-time students is also neglected.

Both tutor and students lack training and encouragement of using EL tools more effectively. They also lack self-consciousness of using these tools proactively, because these tools have not provided enough benefit to encourage them to do so. Lots of functions remain to be used. Some of these functions, e.g., video lecture, discussion board and group communications, if made available, would be very much welcomed by part-time and distance students.
When the first adoption of EL tools was implemented, the following updating and development is too slow to fulfill the demands. Despite being the dominant users, students' opinion towards the WebCT development is seldom requested.

\section{B. Findings from the Comparison of the Case Study and Reviewed Literature}

Comparing the case study with the literature presented in the Second Section, the following research findings are proved to exist in practice.

- The pedagogical aspect as to how EL could be used to improve teaching and learning is hardly addressed.

- The integration of EL in teaching and learning strategy is still largely limited.

- How far staff should be supported in order to achieve the effective use of ICT remains unexplored.

- The issue to integrate into staff timetables to replace face-to-face relationship to online tutoring also remains unexplored.

- Adequate ICT training and raising of ICT skills level as a whole for the academic staff is not sufficient.

The gap between theories and practices are summarized in the following table (Table 3).

\section{CONCLUSIONS}

Back to the question proposed in Section Two of whether EL-based teaching and learning will supersede the traditional education model, the answer from both primary research and through reviewing available literature is 'no' at the moment and for the near future. This also applies to distance learning programs, which was verified from the primary research. The main reason of this is because, to most of teachers and educationist, EL tools are only tools that facilitate the teaching activities. They have not been recognized and has yet become as part of teaching strategies. Therefore, currently, the most likely model to be used in HEIs is the classroom and virtual blended model. However, through using various e-learning tools, students' learning experiences have been largely improved. This research also reveals that the development of EL integration in the learning and teaching process within HEIs is still very slow, given that there is a no clear need to change apart from the trends of EL literacy. EL implementation has not radically affected education as a whole. The demands from distance students and part-time students have not been emphasized in EL programs.

The next stage of this study is to go back to the student to explore hiding reasons behind survey answers by using focused ground interview method. Another survey and focused ground interview will be done among tutors to investigate their utilization and evaluation of WebCT.

As it is indicted in Section Two that "the level of quality in terms of web-based teaching should be make aware to ensure the quality of learning" (Breen, et al. 2001), quality as one the key elements in EL research has 
not yet been considered in this first stage of the study. Therefore, it will be included in the next stage of this research.

TABLE III. THEORIES AND PRACTICES COMPARISON

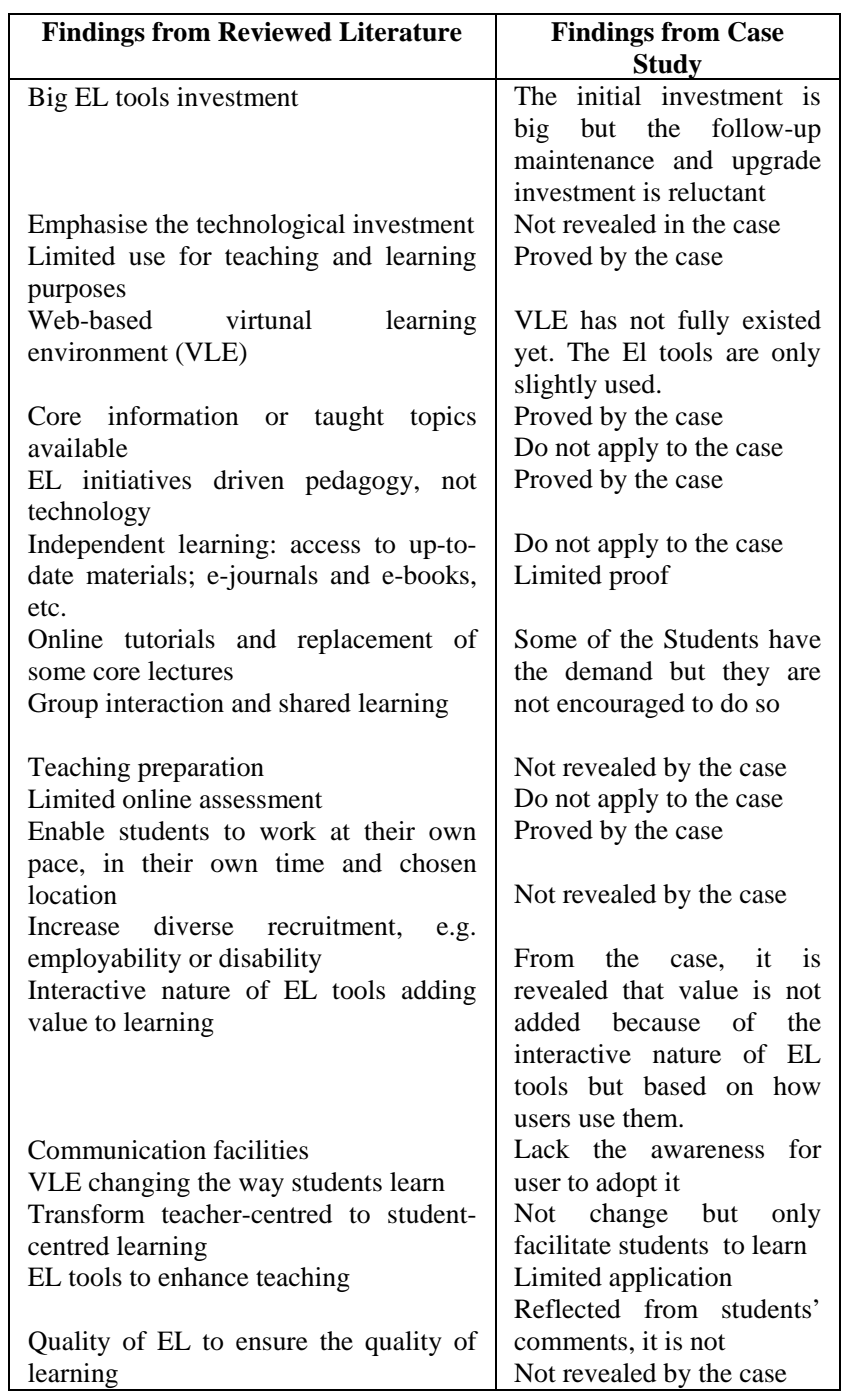

\section{REFERENCES}

[1] Alexander, S. (2001), E-learning developments and experiences, Education+Training, Vol. 43 No. 4/5 240-248.

[2] Bates, A.W. (2000), Managing Technological Change: Strategies for College and University Leaders, San Francisco: Jossey-Bass.

[3] Becta (2008), Improving learning through technology, online available from: http://publications.becta.org.uk/display.cfm(07/04/2008)

[4] Bhanot, R. and Fallows, S. (2005), Quality Issues in ICTbased Higher Education, London: Routledge Falmer.

[5] Breen, R., Lindsay, R., Jenkins, A. and Smith, P. (2001), The role of information and communication technologies in a University learning environment, Studies in Higher Education, Vol. 26 No. 195-106

[6] Carlsson, S.A. (2003), "Knowledge managing and knowledge management systems in inter-organizational networks”, Knowledge and Process Management, Volume 10 Issue 3, p.194 - 206.

[7] Collis, B. and van der Wende, M. (2002), Models of Technology and Change in Higher Education: an international comparative survey on the current and future use of ICT in Higher Education, Enschede: CHEPS/Toegepaste Onderwijskunde

[8] Duffy, T. And Cunningham, D. (1996), Constructivism: Implications for the design and delivery of instruction, Handbook of research for educational telecommunications and technology, 170-219, New York: MacMillan

[9] Ellis, R.A. and Moore, R.R. (2006), Learning through benchmarking: developing a relational, prospective approach to benchmarking ICT in learning and teaching, Higher Education, 51 351-371.

[10] Fallshaw, E.M. (2000), IT planning for strategic support: aligning technology and vision, Tertiary Education and Management, 6(3) 193-207

[11] Issroff, K. and Scanlon, E. (2002), Using technology in Higher Education: an activity theory perspective, Journal of Computer assisted learning, 18 77-83.

[12] Lewis, D. and Goodison, R. (2004), Enhancing learning with information and communication technology (ICT) in Higher Education, University of Wolverhampton, ISBN 1 844782255

[13] Löfström, E. And Nevgi, A., From strategic planning to meaningful learning: diverse perspectives on the development of web-based teaching and learning in higher education, British Journal of Educational Technology, Vol. 38 No 2 312-324

[14] Martin, A. (2002), Concepts of ICT literacy in Higher Educations, online available from: http://www.citscapes.ac.uk/products/backgroundreports/fil es/concepts_ict_HE.pdf (25/03/2008)

[15] McDonough, W.R. (1986), The Aeneas Project implementing the Nelcon Report at Queen's University, Belfast' University Computing , 8 113-115.

[16] Oliver, R. (2002), The role of ICT in Higher Education for the 21st century: ICT as a change agent for education, online available from: http://elrond.scca.ecu.edu.au/oliver/2002/he21.pdf (25/03/2008).

[17] Qi, B., Liu, L., Wang, C., Oliver, S. and Zhang, R. (2009), Can ICT replace traditional learning model? a case study, In Proceedings of the International Symposium on Education and Computer Science (ECS2009), volume 3, p.715-719

[18] Roffe, L. (2002), E-learning: engagement, enhancement and execution, Quality Assurance in Education, Vol. 10 No.1. 40-50.

[19] Selwyn, N (2006), The use of computer technology in university teaching and learning: a critical perspective, Journal of Computer Assisted learning, 23 83-94.

[20] Stensaker, E.A. (2007), Use, updating and integration of ICT in Higher Education: linking purpose, people and pedagogy, Higher Education, 54 p.417-433.

[21] UNESCO, "EDUCATION: Developing National Policies" (2003) University of Bolton website, http://www.bolton.ac.uk/AboutUs/Home.aspx (18/10/2008)

[22] Yin, R. (2003), Case Study Research - Design and Methods, third edition, Thousand Oaks: Sage Publications.

Baomin Qi (PhD) is senior lecturer of Bolton Business School at the University of Bolton. Her research focuses on the topics of development of e-business strategy, e-supply chain management, systems integration, and e-learning. Her research 
work has been published in a range of international refereed conferences and Journals. She is currently supervising three $\mathrm{PhD}$ students. Her teaching focuses on the innovative e-business, e-marketing and projects management, and she has supervised over 50 Master's theses. Prior to pursue her academic career, she had worked within manufacturing industry for ten years as senior engineer, and gained first hand experience of engineering design and innovation.

Lu Liu is a researcher and a part-time lecturer for the BLIS Research Centre at the University of Bolton, UK. From 1990 to 2000 she has worked as a business analyst and a lecturer for each 5 years in China. From 2001, she has studied and worked in several countries, including Norway, Sweden and the United Kingdom . She is interested in the research fields of management information systems, knowledge management and e-learning/training implementation and development. Her research interests have led to a considerable number of high quality publications. She is always looking forward to collaborations from similar ambitions.
Dr Chengbo Wang had been working for nine years in industry, with an extensive experience of industrial engineering, supply chain management, project management and the application research of academic theories into real world operations. After he joined the academic world, both in his $\mathrm{PhD}$ research in Denmark and latter work in Glasgow Caledonian University, he keeps doing research and publishing papers, besides other academic activities. His academic foci include: Logistics Management/Supply Chain Management, Operations Management, Knowledge Management, Case-Based Reasoning, Quality Management, Manufacturing Strategy and Educational issues within operations and supply chain management. Besides cooperation network in academia, Dr Wang also has extensive links and collaboration with industries both in UK and other countries. 